Љиљана Марковић

ljiljana.marković@gmail.com

Милица Јотов

mimijotov@gmail.com

Универзитет у Београду

Филолошки факултет

https://doi.org/10.18485/ai_savremeni_roman.2020.ch7

821.521.09-31"20“

Оригинални научни рад

\title{
ЈАПАНСКА ДИЈАСПОРА И САВРЕМЕНИ РОМАН
}

Јапанска дијаспора и њен литерарни опус у нашем времену сагледавамо кроз призму утицаја јапанских писаца који живе широм света (у Канади, САД, Европи, Латинској Америци) и неретко стварају на другим језицима.

Ово је друга фаза утицаја књижевности Запада на Јапан, јапанску културу и књижевно стваралаштво. Прва фаза је испољила своје пресудно дејство на стварање предуслова за настанак модерног Јапана још у другој половини 19. века, после 1868. године. Тада је преводна књижевност утицала на развој јапанског језика, настанак нових књижевних жанрова и допринела успешној модернизацији Јапана.

У другој фази, која се одвија пред нашим очима, јапански писци значајно доприносе уобличавању слике Јапана у свету данас, као и слике света у Јапану. У овом раду, кроз призму опуса Казуа Ишигуроа, добитника Нобелове награде за књижевност за 2017. годину, који је рођен 1954. године у Нагасакију, а од 1960. године живи у Уједињеном Краљевству, сагледава се књижевно стваралаштво овог писца на енглеском језику, које представља јединствени интерфејс између „талената Запада и духа Истока“, што је био један од водећих постулата изградње савременог Јапана. Ишигуро је истовремено британски, јапански и светски писац који остварује јединствен утицај на развојни 
пут савременог романа и тиме отвара трећу фазу „романа у модернизацији”.

Кључне речи: роман, Казуо Ишигуро, модернизација, књижевна дијаспора

\section{Увод}

Овај рад има за циљ да теоријски и емпиријски, а кроз призму књижевног стваралаштва јапанских писаца који живе широм света, испита утицај јапанске књижевности на литературу Запада, као и Источне филозофије на мисао Запада.

Јапан је прва земља у Азији која је успешно и релативно брзо прошла кроз период модернизације, и послужила као парадигма свим осталим суседима у окружењу. Књижевност као огледало и сведочанство свих друштвено-историјских прекретница представља рефлексију низа промена које су уследиле и урезале се дубоко у свест Јапанаца, без обзира на њихово место боравка. Јапанска дијаспора пролази кроз период адаптације у свим сегментима живота, а књижевници добијају једно потпуно ново виђење света које сазрева као плод спајања култура Истока и Запада. Прва фаза књижевног модерног развоја изнедрила је велике ствараоце попут Мори Огаија и Нацуме Сосекија (IX век). Друга фаза развоја подарила је човечанству велика књижевна дела (XX век); Јасунари Кавабата 1968. године добија Нобелову награду за приповедачко мајсторство, које са великом осећајношћу изражава суштину јапанског духа, као први Јапанац који је понео ово високо признање, а затим 1994. године и Кензабуро Ое. Другој касној фази припада и Казуо Ишигуро, члан јапанске дијаспоре који 
постаје нобеловац 2017. године, започевши тиме трећу фазу развоја јапанске модерне књижевности (XXI век).

Ишигуроова дела представљају софистицирану фузију двеју култура са формом Запада и духом Истока.

\section{Казуо Ишигуро - роман између Истока и Запада}

Казуо Ишигуро је јапански писац који живи и ради у Великој Британији, мада га врло често називају енглеским књижевником јапанског порекла.

Наиме, Ишигуро је рођен у Јапану 1954. године у Нагасакију, а у Енглеску одлази као петогодишњи дечак са својим родитељима. Проћи ће готово 30 година до прве посете Јапану, након исељења. Иако одраста у типичној јапанској породици која негује традицију и обичаје своје земље, неминовно је, и константно изложен утицају англосаксонске културе, што му проширује видике, оштри перо и оплемењује душу. Енглез у Јапану и Јапанац у Енглеској, Ишигуро још у најранијем животном добу схвата важност разумевања различитих култура, што ће га умногоме одредити као писца који, дубоко загледан у људску душу, мајсторски говори о емоцијама и дељењу истих, упркос зидовима и баријерама које је човек са̂м створио. Чињеница је да билингвално и бикултурално окружење утичу на брушење уметниковог космополитског духа и доприносе развоју изузетне емотивне и социјалне интелигенције и комуникацијских вештина. Тако је Ишигуро у свом малом, дечјем свету врло брзо схватио да постоји огромна разлика између тога како треба да се понаша у свом дому, где је говорио јапански, а како напољу, где је користио енглески језик за споразумевање. Синхронијско усвајање два различита културна миљеа, 
две социјалне норме и два различита језика несумњиво утичу на стварање јединственог и препознатљивог књижевног стила који ће 2017. године Ишигуроу донети Нобелову награду. Наслов његовог говора приликом примања Нобелове награде је: My Twentieth Century Evening - and Other Small Breakthroughs.

Ишигуро не само да је био странац у земљи у којој је живео, он је био и странац из земље са лошом послератном репутацијом. Јапан који се попут феникса издиже из пепела опустошене и озлоглашене фашистичке силе, не само да постаје „економско светско чудо”, ${ }^{40}$ већ успева да произведе бисере дијаспоре јапанске савремене књижевности, попут Казуо Ишигуроа и Харуки Муракамија. Деца Јапана која живе у страним земљама, пишу на страном језику, заправо су месије јапанске културе и део су велике машинерије која је освојила свет, а позната под називом „мека моћ Јапана”. Као што је суши постао симбол престижа и заузео значајно место на трпези и у култури Запада, манга у периодици, сакура у дизајну баште, аниме у кинематографији, минимализам у архитектури, кимоно у моди, геџети и роботика у савременој технологији, Тојота у аутомобилској индустрији, тако је Ишигуро, као и његов савременик и колега Мураками, постао најчитанији јапански писац Запада са мисијом да свету отшкрине врата богате културне ризнице Земље излазећег сунца, представи Јапан и оно што га таквим чини. Ишигуро је поносан на своју домовину која успева да од омражене непријатељске земље освоји титулу најпопуларније тачке на планети. Непретенциозни патриотизам избија из сваког слова овог уметника, без тенденције

40 Према: Љиљана Марковић, Милица Јотов, Сања Раденковић и Никола Бацковић, Јапан у праскозорје модернизације. 
да сузбије његов космополитски дух и алтруизам. Као син мајке која је са осамнаест година преживела бомбардовање Нагасакија, он дубоко саосећа са људском патњом и апелује на савест појединца и колектива да се треба окренути духовним вредностима и интегрисању добрих људи, у циљу цивилизацијског напретка. Иако директан потомак жртве атомског бомбардовања, у њему нема горчине и жеље за осветом, само вапај за спасење света. Као што Ишигуро каже, наш однос према прошлости одређује какве ће нам бити садашњост и будућност. Јапанци поштују прошлост, претке, традицију... али су спремни да уче и усвајају нова знања.

Боб Дилан, Леонард Кохен, Џони Мишел (Bob Dylan, Leonard Cohen, Joni Mitchell) су утицали снажно на музички и књижевни укус овог уметника. Ишигуро је музичар који се бави књижевношћу и писац који се бави музиком. Његов уметнички геније успева да симфонијом речи опише неописиво, да пренесе непреносиво и открије најскривеније тајне људске душе.

Као што је музика веома утицала на сазревање његовог уметничког генија, тако је јапанска манга, врста стрипа, одредила његов књижевни правац. Манга ${ }^{41}$ је стрип или графички роман настао у Јапану.

Како сам каже у „Ексклузивном интервјуу са Казуо Ишигуроом“ за НХК (NHK) петак, 8. децембар 2017, ,... литература не мора бити веома озбиљна, свечана и велика. Знате, често се оно о чему причамо може догодити кроз хумор и забаву. Ја верујем у све ове облике приповедања - рецимо, биоскоп, телевизија, позориште; у Јапану имате мангу. Све су ово форме уметности. То је начин на који размењујемо своја осећања, о томе како

41 Овај стил писања настао је крајем 19. века. Има дугачку и комплексну предисторију у ранијој јапанској уметности. Израз манга у Јапану се користи и за стрипове и за стил цртања. 
је живети у овом свету. Мислим да нам помаже да погледамо и испитамо себе, као и да разумемо људе упркос свим баријерама. Верујем да је то врло важан део људског подухвата“.

Такође, Ишигуроа је увек дубоко фасцинирала јапанска култура, нарочито јапански филмови. Како каже, посебан однос има са јапанским филмовима који су настали 1950-их јер му враћају сећања на рано детињство. Пошто су његови родитељи напустили Јапан 1960. године, њихова верзија Јапана коју је наследио је „Јапан који можда данас не бисте препознали“. Ствари су се толико промениле. Када гледа филмове режисера попут Озуа или Нарусеа, осећа да је то нешто веома блиско животу који је имао у Енглеској, у родитељском дому. Ти филмови га подсећају на живот његових родитеља. Због тога је увек имао дубоку везу с јапанском кинематографијом педесетих и раних шездесетих година XX века

\section{Теорије о билингвалности и бикултуралности}

Неуролингвистика и психолингвистика проучавају процесе стварања, разумевања, меморисања, перцепирања језика билингвалних говорника у монолингвалним и билингвалним језичким модалитетима. Психолингвистика настоји да објасни механизам активирања оног језика који је говорнику у датој ситуацији кориснији алат у процесу споразумевања и који је адекватнији у одређеном културолошком контексту.

Билингвизмом се сматра способност појединца или члана заједнице да ефективно користи два језика. Билингвизам је веома честа појава. Билингвизам, сматра Грожан, није само карактеристика језичког говорног подручја у ком се користи два или више службених је- 
зика, као што је случај у Канади или Швајцарској, већ је део готово сваке друштвене групе у готово свакој земљи.

Билингвизам не дефинише нужно само одлично познавање писаног и говорног облика језика којима појединац влада, већ и делимично владање тим језицима. Врло је ретка појава да говорник подједнако влада обама својим језицима, првим језиком (J1) и другим језиком (J2) (Grosjean 1982: 1). Некада се сматрало да билингвизам подразумева владање двама језицима на нивоу изворног говорника. Међутим, данас се сматра билингвалним говорником свака особа која има минималне компетенције у једној од четири језичке вештине (слушање, говорење, читање и писање) на језику који се разликује од његовог матерњег језика (Hamers i Blanc 1989: 6). "Bilingual: Hearing, speaking, spoken or written in, two languages". (Concise Oxford Dictionary).

С обзиром на чињеницу да језик истргнут из културолошког контекста не само да не мора обавити своју основну функцију - да омогући споразумевање, већ може потпуно удаљити учеснике у комуникацији од схватања смисла поруке. Овде је умесно позвати се и на теорију о бикултуралности коју су развиле Фини и Девич-Наваро (Phinney\&Devich-Navarro, 1997). Оне издвајају два основна типа бикултуралности:

1. Мешовиту бикултуралност (blended biculturalism)

2. Наизменичну бикултуралност (alternating biculturalism)

Прва се односи на особе чији идентитет садржи елементе обеју култура, док се друга односи на особе којима је удобно и у једној и у другој култури.

Канадски психолог Бери (J. Berry, 1990; према Phinney\&Devich-Navarro, 1997) указује на феномен акултурације или бикултуралности у одређивању етничког идентитета. Интегрисаним појединцима сматра особе које су задржале елементе своје традиције и кул- 
туре, а истовремено прихватиле и уклопиле се у културу земље домаћина. Асимилованим појединцима сматра особе које су доминантно преузеле модел културе земље домаћина, уз незнатно задржавање елемената из аутентичног културног обрасца. Етнички маргинализованим појединцима сматра особе које су задржале веома мало елемената своје изворне културе, а нису се уклопиле у културу којој су изложене, те су етничкокултуролошки потпуно дезоријентисани.

Ишигуро је у интервјуу за The Art of Fiction (no. $196,2008)$ оценио свој матерњи језик као „ужасно лош”, иако је у родитељском дому увек говорио матерњим језиком. На овом месту, аутори текста указују на специфичност савладавања јапанског језика као страног, јер учење истог захтева четири пута више времена него савладавање било ког језика са подручја Европе. Јапанско компликовано писмо садржи четири врсте писма: хирагану, катакану, канђи и ромађи, а описмењавање је процес који траје целог живота, с тим што се током 12 година основног и средњег образовања завршава циклус усвајања довољног броја идеограма, што је прописало Министарство просвете Јапана Тојо Канђи (То̄ӯ Kanji, 当用漢字 $)^{42}$ (1946), 1850 карактера који се користе у школи, уџбеницима, наставном материјалу.

Ишигуро је као ђак обданишта које је похађао у Нагасакију, научио основно писмо хирагану, али се надаље школовао у Енглеској, стекао образовање на

42 Тојоканђи, такође познат као Тојоканђихјо (当用漢字表, „листа канђија за општу употребу“), резултат је реформе идеограма кинеског порекла у јапанском писму. Јапанско министарство образовања (文部省, monbushō) 16. новембра 1946. године прогласило је ову листу званичном, те се у званичним владиним документима смеју користити само дати карактери; тако да је ова листа постала стандард основне писмености. Листа од 1850 знакова постала је основа за задовољавајућу функционалну писменост на нивоу средњег образовања. 
енглеском језику, тако да је био ускраћен за учење осталих јапанских писама, те се у том смислу нашао у улози студента јапанског језика као страног, у процесу описмењавања на јапанском језику. Како је за овладавање страним језиком потребно знање из све четири категорије (говорење, слушање, писање и читање), Ишигуро остаје „недовршен” у ортографском сегменту, те стога свој јапански језик ниско самовреднује. Помало парадоксално, веома често је дословно преводио реченице са јапанског на енглески језик током процеса стварања књижевног дела. Као што је Ишигуро сам рекао: „At times I found myself translating Japanese phrases and pleasantries quite literally. But most of the time it was a case of finding an eleganty et slightly stilted register that would suggest the rhythms and stylised formality of the Japanese language running all the time behind the English." (The Art of Fiction, no 196, 2008) (сопствени превод: Понекад сам хватао себе како преводим фразе и исказе поштовања са јапанског језика, и то прилично буквално. Али, углавном сам проналазио елегантне форме, додуше не потпуно у духу енглеског језика, које би се ипак одликовале ритмом и углађеном формалношћу јапанског језика.“) Не треба пренебрегнути чињеницу да је Ишигуро прву спознају света доживео на матерњем језику.

С друге стране, Ишигуро се не осећа инфериорно у погледу свог етничког и културолошког идентитета. Како сам каже, у кинематографији великих јапанских уметника, попут Озуа, који често за тему има јапанску традиционалну породицу, налази свој етнички одраз и присећа се детињства и одрастања у типичној јапанској породици. Очувању осећаја етничке припадности доприноси и жеља његових родитеља да се врате у домовину, без икаквих планова да заувек остану у Енглеској. Отац, научник океанограф, Енглеску доживљава 
као земљу у којој ће провести извесно време радећи, а након истека радног уговора природно вратити у матичну земљу. Тачно у тој тачки непоимања будућности у страној земљи, налазимо упориште Ишигуроовог јапанског идентитета. Јапанска култура је потка његовог одрастања, одгоја и образовања. Баш као што је Јапан успео, захваљујући спајању традиционалног и модерног, усвајајући жељно знања са Запада, а никад се не одрекавши своје традиције, тако је и Ишигуро наоружан знањем Запада, накалемљеним на чврсте темеље јапанског духа и културе, постигао светски успех и освојио Нобелову награду. Мото модернизације Јапана 和魂洋 $才^{43}$ је оличен у стваралаштву нобеловца Ишигуроа.

Епски супстрат је био Јапан, јер је то за Ишигуроа била мистична, митска, узвишена цивилизација у којој је увек могао наћи духовно уточиште. Не треба пренебрегнути чињеницу да је Ишигуро прву спознају света доживео на матерњем језику.

Он је растао у специфичном систему моста између Јапана и Запада, и имао у својој подсвести да је јапанска култура, кохерентнија и бољег садржајног формата. Ишигуро радњу свог првог романа који издаје 1982. године A Pale View of Hills („Нејасна слика брегова”) смешта у Јапан.

То је осмишљени Јапан, створен у његовој души, Јапан који у стварности није видео пуних двадесет девет година. На овом месту је умесно упоредити доживљај домовине код наше деце из дијаспоре којој је Милош Обилић херој, идол, синоним за храброст, чојство, симбол праведности, окриља мајке Србије која шири руке ка својим чедима расутим по свету, вазда спремна да их пригрли и стави на своје топле скуте. За разлику од

43 Wakon yousai, јапански дух са знањем Запада. 
деце која живе и расту у Србији, њихови вршњаци у туђини носталгично негују у својим душама митове, народне песме и приче о јунацима, уз један сасвим другачији доживљај. Они се, глорификујући и величајући своју вољену родну груду, везују за њу упркос географској, језичкој и културолошкој дистанци. Управо та представа похрањена у подсвести чува етнички идентитет људи из дијаспоре. Тако је и Јапан као узвишена уметничка инспирација, постојао само у Ишигуровој души. Суштина и снага његове речи лежи у сазнању да постоји алтернативност у овом сувише шематизованом свету, а то је његов митски, узвишени Јапан.

Ишигуро је за стварање својих романа преузео западну форму, док је суштински перцепција времена и простора остала примордијално, есенцијално јапанска. Ишигуро 1986. године издаје роман An Artist of the Floating World (Сликар пролазног света). Концепт плутајућег света 浮世 (ukiyo, укијо) представља централну зен-будистичку мисао јапанске културе, засновану на постулатима ове, пре филозофије него религије - лепота пролазности и пролазност лепоте; ићи го ићи е 一期 一会 ${ }^{44}$ (one chance only once, тренутак који се никада не понавља). Живот јесте пролазан, али је увек временски сублимиран у једној тачки; неоконфуцијанци су дали оквир за овакво виђење света. На замишљеној X оси се налази наша свест о пролазности, док се на Y оси налази тренутно. Ми живимо у пресецима времена X и

44 Пролазност лепоте, као и лепота пролазности чине потку јапанске културе. Ова култура диви се трешњином цвету, који симболише важност непоновљивог тренутка - ићи го ићи e - 一期一会 (one chance, only once), према: Милица Јотов, Социолингвистичка анализа језика штампе у јапанском језику, монографија, Задужбина Андрејевић, 2015, ISBN: 978-86-5250240-0 
Y линије на графикону људског бивствовања. У сваком цвету, башти, сублимиран је простор читавог универзума. Зато се цео Јапан клања лепоти трешњиног цвета негујући традицију кроз ритуал ханами (花見息息), посматрање сакуре ${ }^{45}$ 桜 у пролеће, док Запад остаје нем и несвестан промена у природи.

Зен-будистички концепти ваби саби 侘び寂び(савршена лепота проузрокована несавршеношћу); гири 義理 (дужност, обавеза враћања дуга кроз доживотно, пожртвовано, лојално служење надређеном); шакеј ${ }^{46}$ 借景 (у архитектури - пејзаж позајмљен из природе, у Ишигуроовим романима Јапан као позадина енглеске литерарне сцене); укијо浮世 (плутајући свет као симбол пролазности), конфучијанство као први слој чврстог темеља јапанске културе, тако су дубоко урезани у Ишигуроову подсвест да Јапан даје ритам, мелодију и такт свим његовим делима и чине га писцем јединстве-

45 Трешњино стабло стоји голо и празно годину дана да би цео Јапан изашао да се поклони лепоти трешњиног цвета, који се може видети свега неколико дана у току године. Сличан смисао има и чајна церемонија, или лепота гејше, па чак и ритуално самоубиство. Све ово заједно припада плутајућем свету - укиуо 浮き世. Овај концепт, преко укиуое слика, извршио је огроман утицај и на уметност запада, нарочито на импресионисте попут Ван Гога и Монеа, према: Милица Јотов, Филолошки факултет, Универзитет у Београду, докторска дисертација 2013, Социолингвистички аспекти језика у периодици Јапана у доба „продужене стагнације“ (2000-2010).

46 „Реч шакеј је у свакодневни језик, тзв. свакодневни језик 日常会話 (у коме је латентно присутна, али не и веома експлоатисана) дошла из филозофије, културе, и, последично, архитектуре зена. Њен смисао најбоље се може схватити једино уколико се физички присуствује феномену позајмљивања пејзажа из природе.“ - према: Милица Јотов, Филолошки факултет, Универзитет у Београду, докторска дисертација 2013, Социолингвистички аспекти језика у периодици Јапана у доба „продужене стагнације“ (2000-2010). 
ног и препознатљивог стила својственог само њему саMOM.

Остаци дана (The Remains of the Day - 1989), poман по којем је снимљен одличан филм са Ентони Хопкинсом и Емом Томпсон, је Ишигуроов трећи роман. Оданост господару и осећај дужности које Ишигуроов јунак ставља изнад личних емоција, пожртвованост, истрајност, извршавање задатка без преиспитивања исправности и оправданости издате му наредбе, неке су од самурајских врлина, заснованих на постулатима бушидо кодекса ${ }^{47}$ које заједно са готово пословичном британском хладноћом дају овом роману савршену композицију „трећег универзума”. Социолингвистичка теорија о идентитету и заједници, Теорија о трећем свету, трећем универзуму "Sociolinguistic Theory the Third Space", даје одговор на питање како је Ишигуро створио јединствен и препознатљив, само њему својствен књижевни стил. Ишигуро је успео да се изгради паралелно и независно у обе културе, што му је дало јединствену перспективу; ону која укључује обе културе, али даје и свежу слику, нови квалитет који је независан ентитет и не фаворизује ниједну од њих. Лица Јапанаца и Британаца без експресије емоција карактеристика су њиховог националног карактера. Показивање осећања се у обе културе сматра недоличним, инфантилним, неуглађеним понашањем. Такво понашање својствено је деци и варварима, јер се на њиховим лицима може

47 武士道; 武士 - ратник; 道 - стаза, пут обухвата морални кодекс и животну филозофију ратника који су припадали аристократском слоју средњовековног јапанског друштва. Дискусија о овом питању је тема бројних места у књизи „Правни систем Јапана“. Према: Љиљана Р. Марковић, Радомир М. Ђуровић, Правни систем Јапана, издање: Филолошки факултет, Кокоро, Београд 2016. 
прочитати све што осећају (радост, љутња, бес...). Даље, лице на ком се не виде емоције, имплицира утицај древне уметности на Ишигуроа - Но драме. ${ }^{48}$ Но драма је врста јапанске музичко лирске драме из 12. века, засноване на будистичкој религији, јапанској митологији, животном искуству и историји. Глумци током представе носе маске, исклесане из блокова чемпреса; кључни су део традиције која траје готово 1000 година, а представљају фигуре демона и монаха.

Традиција и дух Јапана и у роману Закопани цин (Buried Giant) избијају из подсвести Ишигуроа, као књижевни шакеј из перспективе Западњака. Писац позајмљује елементе матичне културе апсорбујући лепоту јапанских митова и легенди које вешто комбинује са Толкиновом фантастичном прозом и једноставним језиком бајке, да би свету помогао да се сети правих вредности дубоко закопаних у сећању појединца и колектива. Клетва змаја пада на сећање јунака који се кроз измаглицу заборава боре против зла.

\section{Рани писци XIX и XX века}

Први писци су отворили флуидни пут између западног романа и јапанске новеле, романа 小説Шосецу,

48 武士道; 武士 - ратник; 道 - стаза, пут обухвата морални кодекс и животну филозофију ратника који су припадали аристократском слоју средњовековног јапанског друштва. Дискусија о овом питању је 48 Ово питање је разматрано на више места у књизи Правни систем Јапана. Према: Љиљана Р. Марковић, Радомир М. Ђуровић, Правни систем Јапана, издање: Филолошки факултет, Кокоро, Београд 2016. тема бројних места у књизи „Правни систем Јапана“. Према: Љиљана Р. Марковић, Радомир М. Ђуровић, Правни систем Јапана, издање: Филолошки факултет, Кокоро, Београд 2016. 
物語Моногатари, 漫画 Манге.

夏目漱石Нацуме Сосеки (Natsume Souseki) je jeдан од најплоднијих књижевних стваралаца IX века. У Јапану га сматрају најзначајнијим писцем савремене књижевности тог доба, јер је као академик британске књижевности одлично познавао културу Запада, те утицао на све велике уметнике који ће наставити његовим путем до сусрета двеју култура на раскрсници Истока и Запада. Сосекијев допринос књижевности је велики исто колико и његов допринос бољем међусобном разумевању двеју култура.

Такође, један од водећих писаца савремене јапанске књижевности и први књижевник који је успешно изразио дух западне поезије на јапанском језику јесте 森 鴎外 Мори Огаи (Mori Ougai). Његов преводилачки опус немачке књижевности је веома значајан. Познавање конфуцијанских класика, као и проучавање рангакуラン学 (холандски језик и наука), познавање кинеске поезије, одлично владање немачким језиком, познавање медицине (био је најмлађи лекар који је икада добио лекарску лиценцу у Јапану), свестрано образовање стечено у Јапану и Европи, учинили су га мајстором превођења и ствараоцем јединственог књижевног стила који је представљао мешавину многих језика и култура усвојених током његовог живота, као последица богатог животног искуства. Његова кратка прича „Играчица” бави се компликованим односом у љубавној вези Јапанца и Немице. Огаи je, уз Кавабату, један од писаца који су извршили снажан утицај на савремени роман XIX и почетак XX века.

Јасунари Кавабата ${ }^{49}$ 川端康成 (Kawabata Yasunari) обележава својим књижевним достигнућима XX век

49 Према поговору књиге Снежна земља - Велемајстор. Поговор је саставила Љиљана Ђуровић Марковић. 
као први Јапанац који је добио Нобелову награду за књижевност 1968. године. Назив његовог говора је: Japan, the Beautiful and Myself (美しい日本の私). Образложење за додељену награду било је: за приповедачко мајсторство, које са великом осећајношћу изражава суштину јапанског духа. Кавабатин циљ је био да Јапан каo sui generis ${ }^{50}$ естетску велецивилизацију представи свету као нови могући правац хуманизма. Кавабата је филозофски и интелектуално заинтригирао Запад скренувши пажњу на традиционалне духовне вредности Јапана и изградивши најчвршћи мост разумевања двеју култура.

Кензабуро Oe (大江健三郎、Ōe Kenzaburo) je други јапански нобеловац и веома значајан писац XX века; писао је под снажним утицајем француске и америчке књижевности.

Познавање других култура и језика омогућава и овом писцу да преузимањем елемената из различитих култура састави мозаик неког бољег, замишљеног света у коме се живот и мит преплићу. Назив његовог говора приликом примања Нобелове награде је: Japan, The Ambiguous, and Myself (あいまいな日本の私).

Свим раним писцима јапанске савремене књижевности је заједничко виђење неког новог, другачијег, бољег света у коме се људи разумеју, поштују и чувају једни друге, упркос језичким и културолошким баријерама. Свако је од њих имао своју алтернативну домовину (二番目の故郷, niban me no furusato) за коју се чврсто везао кроз проучавање и упознавање језика и културе, баш као што су и аутори овог рада доживели Јапан који је постао њихова „друга домовина”.

50 Према: проф. др Љиљана Марковић, предавања о делима Јасунари Кавабате, предмет Запад и Јапанска књижевност, Филолошки факултет. 


\section{Писци јапанске дијаспоре}

Осим Казуо Ишигуроа коме смо у највећем делу овог рада посветили заслужену пажњу, поменућемо још неке запажене књижевнике јапанске дијаспоре. Неки од њих стварају своја књижевна дела на страном језику, као Казуо Ишигуро, док неки од њих, попут Харуки Муракамија и Јоко Таваде пишу на јапанском и страном језику.

Харуки Мураками (村上春樹、Мураками Харуки) је јапански писац који је привукао пажњу домаће као и стране публике широм света. Његови романи су преведени на више од педесет језика. Интересовање за његове романе не јењава.

Мураками је књижевни мађионичар који уме да створи магију на сцени у својим романима и да увуче читаоца у радњу тако снажно да овај заборавља на све што се око њега дешава у реалном животу. Иако је рођен и школовао се у Јапану, Мураками је у једном тренутку одлучио да пише на енглеском, мада је оригинално стварао на јапанском језику. Како је сам објаснио, комплексност матерњег језика је била спутавајућа у његовом случају; а баш чињеница његове ограничавајуће могућности изражавања на енглеском језику и различитост реченичних конструкција су га натерали да поједностави свој израз и ослободи се сувишних компоненти из свог језика. То му је помогло да нађе ритам и развије свој стил. Са тим новостеченим стилом, вратио се писању на јапанском језику. „If you want to talk about something new, you have to make up a new kind of language". (NYTBR, 27.09.1992) (сопствени превод: Ако желиш да причаш о нечем новом, мораш да смислиш нову врсту језика.) Тај „Мураками модел” су прихватили многи писци у тражењу свог аутентичног 
стила. Његов долазак на западну књижевну сцену обновио је интересовање Запада за јапанску књижевност, традицију и филозофију.

Үōко Ташада (多和田葉子, Ташада Үоко) је јапанска књижевница која живи и ради у Немачкој, а пише на оба језика. Она сматра да је језик пре вештачки и магичан, него природан. Пише на немачком и јапанском језику, а често комбинује оба стварајући нове речи које нису разумљиве ни изворним говорницима без увида у другу културу и језик. Тавада сматра да само директна интеракција између различитих култура, а она се најбоље и најбрже остварује путовањима у иностранство, може довести до бољег разумевања.

Егзофонија је термин који се односи на описивање феномена писања на нематерњем, односно страном језику. Иако је овај феномен вековима познат, сама кованица која га објашњава је први пут употребљена 2007. године. Сви горепоменути писци јесу егзофоничари који производе најлепшу музику у симфонији речи, звука, ритма, новоствореног језика њихових иновативних и оригиналних књижевних дела најновије и најмлађе књижевне фазе савременог романа.

Студије су показале да људи који говоре више од једног језика имају ширу глобалну перспективу и другачији приступ животу, што се преноси и у сферу писања на страном језику. Често није само привлачност нових речи и фраза оно што инспирише писца да своје мисли искаже на туђем језику, већ је то прилика да свет прочита и сазна о њему из другачије перспективе. Писци могу лако доживети блокаду и одсуство инспирације на матерњем језику и поново је пронаћи у страном језику који пружа сасвим нову форму изражавања. Помало парадоксално, писање на другим језицима може писца учинити бољим, експресивнијим и ближим читаоцима. 


\section{Закључак}

Казуо Ишигуро је, као и многи његови литерарни претходници, у досадашња три периода модернизације (XIX век, XX век, XX век), успео да прихватајући, и у себи спајајући литерарну традицију Запада са литерарном традицијом Истока, створи величанствене романе који су и Западни и Источни. При томе, Исток нам Ишигуро транспонује кроз најлепше и најчистије елементе књижевне ризнице само његовог, митског Јапана.

Он је још увек човек у добром стваралачком добу, те очекујемо даљу разраду и нове изданке књижевних дела која ће настати на размеђи ових двеју великих литерарних традиција.

\section{Библиографија:}

Grosjean, F. (1982). Life with two languages. An Introduction to Bilingualism. Harvard University Press.

Grosjean, F. (1996). Living with two langauges and two cultures.

U: Parasnis, I. (ur.) Cultural and Language Diversity and the Deaf Experience, 20-37, Cambridge: Cambridge University Press.

Guttman, E. Aphasia in children. Brain, 1942, 65, 205-19. Journal of Early Adolescenc, 9, 34-49.

Lambert, W. Contribution to XXIst International Congress of Psychology, Paris, 1976.

Lenneberg, E. H. Biological foundations of language. New York: Wiley, 1997. Penfield, W. And Roberts, L. Speech and Brain Mechanisms.

Phinney, J. S. (1989). Stages of Ethnic Identity Development in Minority Group Adolescents.

Phinney, J. S. (1990). Ethnic Identity in Adolescents and Adults:

Review of Research. 9 
Roll Over Basho : Who Japan is Reading and Why : a Dialogue Between Jay McInerney and Haruki Murakami. The New York Times Book Review, September 27, 1992.

Thiery, C. A. J. Le Bilinguisme chez les Interpretes de Conference

Professionels. Unpublished Doctoral Thesis, Universite de la Sorbonne Nouvelle (Paris ill), 1975.

Vygotsky, L. S. Thought and Language. Cambridge: M.I.T. Press, 1962.

Јапан у праскозорје модернизације, према: Љиљана Марковић, Милица Јотов, Сања Раденковић и Никола Бацковић.

Јасунари Кавабата. Снежна земља - Велемајстор, поговор је саставила Љиљана Ђуровић Марковић.

Љиљана Р. Марковић, Радомир М. Ђуровић. Правни систем Јапана, издање: Филолошки факултет, Кокоро, Београд 2016. Милица Јотов. Социолингвистичка анализа језика штампе у јапанском језику, монографија, Задужбина Андрејевић, 2015. Милица Јотов, Филолошки факултет, Универзитет у Београду, докторска дисертација 2013., Социолингвистички аспекти језика у периодици Јапана у доба „продужене стагнације" (2000-2010).

Ljiljana Marković Milica Jotov

\section{JAPANESE DIASPORA AND THE MODERN NOVEL}

\section{Summary}

The Japanese diaspora and its literary opus in our time are seen in the prism of the influence of Japanese writers who live around the world (in Canada, the USA, Europe, Latin America) and often create in other languages. 
This is the second phase of the influence of Western literature on Japan, Japanese culture and literary creativity. The first phase proved its decisive factor in creating the preconditions for the emergence of modern Japan in the second half of the 19th century, after 1868. Translated literature then influenced the development of the Japanese language, the emergence of new literary genres and contributed to the successful modernization of Japan.

In the second phase, which takes place in front of our eyes, Japanese writers significantly contribute to shaping the image of Japan in the world today, as well as the image of the world in Japan. In this paper, through the prism of the opus of Kazoo Ishiguro, the Nobel Prize laureate for 2017, born in 1954 in Nagasaki, and since 1960, he lives in the United Kingdom, the literary creation of this writer in English is taken into consideration, which represents a unique interplay between the «talent of the West and debt of the East,» which was one of the leading postulates for the construction of modern Japan. Ishiguro is also a British, Japanese and world writer who has a unique influence on the developmental path of the modern novel.

Key Words: novel, Kazuo Ishiguro, modernization, literary diaspora. 